\title{
Purple Seed Stain Incidence Among Soybean Cultivars and Between Seasons in Puerto Rico ${ }^{1}$
}

\author{
Paul R. Hepperly ${ }^{2}$
}

\begin{abstract}
Nine soybean cultivars (Buffalo, Cobb, Davis, Hardee Late Selection, IAC2, Improved Pelican, Jupiter, Orba, and Ransom) were planted at 11 dates from February 15, 1979 to October 1, 1979. At harvest maturity, the purple stained seeds from each of two 100 -seed samples from each cultivar at each planting were counted. Variation in the incidence of purple seed was associated with cultivar and planting date. The highest overall incidences of purple seed were associated with Ransom $(9.50 \%)$, Jupiter $(8.27 \%)$; the lowest, in IAC-2 $(0.29 \%)$, and Improved Pelican $(0.23 \%)$. Precipitation and temperature levels were not associated with incidence of purple stain. Purple stain incidence was highly correlated with length of photoperiod at time of planting ( $r$ $=-0.72)$; at 30 days after planting $(r=-0.97)$; and at 75 days after planting $(r=-0.79)$. Shortened photoperiods appear to predispose soybean plants to purple stain. This fact may help explain the increased severity of purple stain in tropical areas compared with that in the temperate zones.
\end{abstract}

\section{INTRODUCTION}

Soybean (Glycine max (L.) Merr.) is a grain legume with a high content of excellent quality oil and protein (20). The plant has become a major industrialized crop in the United States, where oil is extracted and protein-rich residues are used as feed supplements. Because protein deficiency constitutes a serious and widespread problem in many tropical areas, increased soybean production and utilization in the tropics may be desirable. The International Soybean Program (INTSOY), which is funded by the United States Agency for International Development (USAID), has supported tropical development and use of soybeans.

The center of soybean production before this century was northern China (22). During the present century, soybean germplasm has been successfully introduced from Oriental production zones into the United States. This transfer has been aided by the similar adaptation zones of the two areas. Introduction of commercial soybean production from temperate and subtropical zones to tropical areas will require more effort.

The soybean is a plant extremely sensitive to daylength for initiating its reproductive processes $(16,17,20,21)$. Long nights promote the

\footnotetext{
${ }^{1}$ Manuscript submitted to Editorial Board November 20, 1982.

${ }^{2}$ Assistant Professor of Plant Pathology, Department of Crop Protection, College of Agriculture, University of Puerto Rico.

The author wishes to acknowledge the editing efforts of Apolinar Sánchez-Miranda, Extension Pathologist, Univ. of P. R., and the support and funding of the Agricultural Experiment Station of the University of Puerto Rico and the United States Agency for International Development through the grant USAID/TA-G-73-50).
} 
change in soybeans from vegetative growth to reproductive growth. The minimum night length, which stimulates the change from vegetative to reproductive growth, varies among soybean lines. At high latitudes the night length which stimulates this change in adapted varieties is longer than the same period for adapted varieties at lower latitudes. On the basis of these periods, soybeans are classified in 12 adaptation groups. When soybeans adapted to high latitudes are planted in low latitudes, reproductive processes are quickly stimulated; the result is greatly reduced vegetative growth and per plant yield. Vegetatively stunted plants mean losses in mechanical harvest and losses from weeds; moreover, increased seeding rates are needed to produce high yields. For these reasons, tropical photoperiods are a major obstacle to stable soybean production.

Besides the problem of insufficient vegetative growth of soybeans under tropical conditions, soybean seed quality is often low because of the constant high relative humidity, rainfall, and temperatures encountered in much of the humid and semi-humid tropics, especially in the lowlands where the majority of tillable acreage is found. Problems with seed quality in the field, during storage, and shortly after planting are related to pathogenic fungi (35). When these fungi are present, uniform stands for good soybean production are unlikely.

Purple stained soybean seed is caused by cercosporin (26), a fungal pigment of Cercospora kikuchii (T. Matsu. \& Tomoyasu) Gardner, an organism which colonizes the inner layers of the soybean seedcoat (10). Besides infecting soybean seed, the fungus can cause leaf spotting and defoliation of field soybeans (38). C. kikuchii is known to infect other hosts (23). Although other species of Cercospora when they are artificially inoculated cause staining of soybean seed (24), in the field, purple stain of soybeans is caused only by $C$. kikuchii (35). Various workers have considered purple stain as either a nonimportant (41) or important (11, 12) disease of soybeans.

Purple staining of soybeans seed can affect seed quality by making them unesthetic for soybean foods (35). Commercial processing of soybeans removes purple stain without additional processing. The United States Department of Agriculture tolerance for purple stain is $5 \%$ for U.S. Grade No. 1 (35), and no more than $15 \%$ for U.S. Grade No. 2 (3). Grading of soybeans seed based on purple stain may be warranted in seeds for food use but not for those destined for commercial oil extraction.

The effect of $C$. kikuchii on seed germination has been debated. Murakishe (29) reported $19 \%$ reduction of germination of seed which were infected by C. kikuchii. Sherwin and Kreitlow (34) did not note reductions of soybean germination associated with $C$. kikuchii infection. Wilcox et al. (39) found that although purple stain had a slight effect in 
lower germination and emergence, agronomic characters such as subsequent yield, purple stain in harvested seed, and plant morphology were not affected. Roy and Abney (32) report that C. kikuchii infection results in the reduction of Phomopsis seed mold. This reduction results in higher germination of seed from purple stain-inoculated plants compared to noninoculated controls. Lehman (28) noted that C. kikuchii reduces field stand by causing post emergence damping-off. Although laboratory germinations may not be lowered by $C$. kikuchii, it is distinctly possible that field stands are. Hepperly and Sinclair (19) found that the purple stain fungus was naturally antagonistic to Phomopsis sp. in northwest Puerto Rico, where purple stain incidence was high but not in central Illinois, where purple stain was low. Working in Puerto Rico, González-Rodríguez (12) found that purple stain can increase damping-off by $20 \%$ compared to that found from nonstained seeds from the same seedlot. Planting $25 \%$ or more purple stained seed resulted in increased purple stain in the subsequent harvest and significant reductions in yield. Diaz (11) in Venezuela noted stand losses from $C$. kikuchii and observed that coastal temperatures in his country were constantly favorable for purple stain development.

Environmental conditions which stimulate sporulation and air dispersal of $C$. kikuchii have been studied (12). Although a sexual stage of $C$. kikuchii has been suggested, its connection with the purple stain fungus is not proved and its importance in purple stain epidemiology is doubtful (35). Under laboratory culture, conidia of C. kikuchii are produced with difficulty (37). Some isolates never form abundant conidia, and others lose this ability when cultured. Sporulation occurs over a range of $15^{\circ}$ to $35^{\circ} \mathrm{C}$, optimally from $23^{\circ}$ to $30^{\circ} \mathrm{C}$. Vathakos and Walters (37) demonstrated that soybean plants require ultraviolet light for sporulation, and that leaf media from senescent soybean plants stimulated abundant conidia formation while leaf media from the same plants in vegetative stages inhibited the same. In the field, C. kikuchii is dispersed diurnally with an optimum at midday when turbulence and relative humidity changes are optimal (12). Drying, which causes conidiophore twisting, is thought to cause conidia release. Maximum number of conidia are trapped at later stages of senescence (12). Light, besides affecting conidia production, can also influence the toxic action of cercosporin. Light in the blue to yellow range $(450$ to $530 \mathrm{~nm}$ ) is required to cause toxicity of the purple pigment, cercosporin, of C. kikuchii and other Cercospora spp. Cercosporin is toxic to cells of plants, animals, and bacteria (9). The influence of light quality and quantity on the development of Cercospora diseases deserves further study in the field.

The susceptibility of the soybean plant to the purple stain fungus varies with plant age. For seed infection, the period of flowering to the 
beginning of pod senescence is important. Agarwal et al. (2) found that benomyl sprays at 25 and 55 days after plant emergence gave complete control of purple stain. Athow $(3,27)$ reported that purple stain control with benomyl was not effective more than 17 days prior to inoculation in the flowering stage and more than 60 days thereafter. Covering developing pods reduced Phomopsis infection of seed but not that of $C$. kikuchii (4). While Phomopsis increases at and after physiological maturity $(18,19), C$. kikuchii appears to infect optimally at flowering and budding. Roy and Abney (32) found that inoculation at full flower with the purple stain fungus gave optimal infection of seed with $C$. kikuchii and optimal reduction of Phomopsis seed mold. Crane and Crittenden (7, 8) found that deflowering soybeans and infection by tobacco ringspot virus prolonged early reproductive stages and increased purple seed stain. Purple stain incidence was correlated with the length of the flowering period but not with pre- and post-flowering periods. Wilcox et al. (40) and Hepperly and Sinclair (19) report the decline of purple stain fungus infection of seed during delayed harvest.

One of the most promising controls of purple stain is development of resistant lines. Purple stain resistance was reported in PI-80837, which produces a maximum of $3 \%$ purple seed and less than $30 \%$ infection even after artificial inoculation $(31,41)$. C. kikuchii infection of seed is usually greater than the number of stained seed (25). Lack of purple seed can occur with a fairly high rate of infection. Han (15) in an extensive screening of soybean lines in China found Pingtung Green Bean, Acadian, Pingtung-chu-tzu-tou, Improved Pelican, Manchu, Kaohsing 1, Kaohsing 19, Black Bean, Kanto 13, Bilofield, Chichibu Musheachin, Dortschsoy, Hale, Ogden, Mandarin, Seminole, and M3234 resistant to purple stain. Wilcox et al. (41), who reported on studies of heritability of resistance from PI-80837 in crosses with the susceptible Amsoy found that resistance was highly heritable in both $\mathrm{F}_{2}$ and $\mathrm{F}_{3}$ progenies. Chamberlain (6) reported that Lee, Ogden, and Roanoke were resistant to purple stain, bud blight, and mosaic. The finding that some, but not all, seed isolates cause foliar spots (1) may indicate the presence of physiological races of C. kikuchii, which may be important in future breeding programs.

There are few field studies which have tried to pinpoint the range of environmental conditions which can either favor or inhibit purple seed stain. Tenne and Sinclair (36) found that in Puerto Rico purple stain was serious at the humid costal plain substation at Isabela (over 16\%) but not serious at the humid hill station of Adjuntas (less than 3\%) or the arid coastal station of Fortuna (less than $3 \%$ ). In my studies a range of cultivars and planting dates was used to find associations of purple stain incidence with environmental fluctuations at Isabela, Puerto Rico. 


\section{MATERIALS AND METHODS}

The experiments were conducted in 1979 at the Isabela Substation of the University of Puerto Rico Agriculture Experiment Station. The site lies $128 \mathrm{~m}$ above sea level at lat. $18^{\circ} 28^{\prime} \mathrm{N}$., with a mean annual minimum and maximum air temperature of $18.9^{\circ} \mathrm{C}\left(66^{\circ} \mathrm{F}\right)$ and $29.4^{\circ} \mathrm{C}\left(84.9^{\circ} \mathrm{F}\right)$, respectively, and a mean precipitation of $1658 \mathrm{~mm}$ (65.3 in) per year. Records were used from the Isabela weather station, Fahrenheit and inch systems for daily minimum and maximum temperatures and precipitation, respectively. Photoperiodic variations were according to Salaues (33). The soil at the substation is a Coto clay $(\mathrm{pH} \mathrm{6.0)}$ classified under modern nomenclature as a Tropeptic, Eutrustox: clayey, kaolinitic, isohyperthermic, Oxisol.

Plantings of the nine cultivars (Buffalo, Cobb, Davis, Hardee Late Selection, IAC-2, Improved Pelican, Jupiter, Orba, and Ransom) were done by hand on 11 dates from February 15 to October 1, 1979. Plots consisted of three 3-m rows on $75 \mathrm{~cm}$ centers. Each cultivar was replicated twice on each seeding date. Approximately 20 seeds were planted per $\mathrm{m}$ row, and plants of the center row of each plot were harvested at maturity. A 100-seed sample from each replication was counted for incidence of purple stain.

Data means for each cultivar at each planting season were calculated and overall cultivar and season means and their standard error were computed. Rain and temperature levels were correlated with purple stain incidence graphically with scatter diagrams and mathematically with simple linear correlation. Cumulative values for the 90 days after planting, for the period 60 to 90 days after planting, and for the period 30 to 90 days after planting were used for temperature and rain data.

\section{RESULTS AND DISCUSSION}

Soybean cultivars Improved Pelican and IAC-2 appeared highly resistant to purple seed stain (table 1). In these cultivars, purple seed never exceeded $3 \%$ in any of the 11 planting seasons. Improved Pelican was reported as resistant to purple stain by Han (15) in China. In other studies $^{3}$ Improved Pelican has shown up to $45 \%$ C. kikuchii infection with less than $3 \%$ purple seed. In this respect, the cultivar appears to act similarly to PI-80837 as reported by Roy and Abney (31). Among the advantages of using Improved Pelican is its low transmission of and tolerance to soybean mosaic virus $(13,14)$. Compared to Improved Pelican, IAC-2 has an advantage of higher yield. To the author's knowledge this is the first report of IAC-2 as a source of purple stain resistance.

${ }^{3}$ P. R. Hepperly, unpublished data. 
TABLE 1.-The influence of cultivar and planting date on the mean incidence of purple stain (Cercospora kikuchii) of soybean (Glycine max) seed at Isabela, Puerto Rico

\begin{tabular}{|c|c|c|c|c|c|c|c|c|c|c|c|}
\hline \multirow{3}{*}{ Planting Date } & \multicolumn{9}{|c|}{ Incidence of purple stain (\%) } & \multirow{3}{*}{$\dot{x}$} & \multirow{3}{*}{ S.E. ${ }^{3}$} \\
\hline & \multicolumn{9}{|c|}{ Soybean cultivars } & & \\
\hline & Buffalo & Cobb & Davis & $\mathrm{HLS}^{2}$ & IAC-2 & $\begin{array}{c}\text { Improved } \\
\text { Pelican }\end{array}$ & Jupiter & Orba & Ransom & & \\
\hline February 15 & $8.5^{1}$ & 10.5 & 10.0 & 12.5 & 0.0 & 1.0 & 5.5 & 3.0 & 17.0 & 7.55 & 1.88 \\
\hline March 1 & 5.5 & 6.5 & 6.0 & 11.0 & 0.5 & 0.0 & 6.0 & 7.5 & 14.0 & 6.33 & 1.48 \\
\hline March 15 & 2.5 & 5.5 & 6.0 & 0.0 & 0.0 & 1.0 & 2.5 & 0.0 & 14.5 & 3.55 & 1.56 \\
\hline April 2 & 2.0 & 2.5 & 1.5 & 0.0 & 0.5 & 0.0 & 2.0 & 0.0 & 6.5 & 1.67 & 0.69 \\
\hline April 17 & 1.5 & 0.0 & 2.5 & 1.5 & 0.5 & 0.0 & 0.0 & 0.0 & 2.0 & 0.89 & 0.33 \\
\hline May 1 & 0.5 & 2.0 & 0.5 & 0.0 & 0.0 & 0.0 & 0.0 & 0.0 & 0.0 & 0.33 & 0.22 \\
\hline June 4 & 1.0 & 0.0 & 0.0 & 0.5 & 1.5 & 0.0 & 6.0 & 1.0 & 2.5 & 1.39 & 0.64 \\
\hline July 2 & 0.0 & 0.0 & 1.0 & 0.5 & 0.0 & 0.5 & 1.5 & 0.0 & 4.5 & 0.89 & 0.48 \\
\hline August 2 & 4.5 & 6.5 & 1.5 & 9.0 & 1.5 & 1.0 & 22.5 & 2.5 & 4.0 & 5.89 & 2.25 \\
\hline September 6 & 8.5 & 13.5 & 14.0 & 11.0 & 3.0 & 0.5 & 23.0 & 13.5 & 10.0 & 10.78 & 2.19 \\
\hline October 1 & 12.5 & 26.5 & 11.0 & 21.5 & 1.5 & 2.5 & 22.0 & 6.5 & 30.0 & 14.89 & 3.50 \\
\hline $\bar{x}$ & $\overline{4.27}$ & $\overline{6.68}$ & $\overline{6.68}$ & $\overline{6.14}$ & $\overline{0.82}$ & $\overline{0.59}$ & 8.27 & $\overline{3.09}$ & 9.50 & & \\
\hline S.E. & 1.22 & 2.39 & 1.46 & 2.19 & 0.29 & 0.23 & 2.83 & 1.32 & 2.60 & & \\
\hline
\end{tabular}

${ }^{1}$ Based on 2 replications of 100 seeds each.

${ }^{2} \mathrm{HLS}=$ Hardee Late Selection.

${ }^{3}$ S.E. = Standard error of the mean. 
Both Improved Pelican and IAC-2 are excellent candidates for use in developing cultivars for tropical areas with increased resistance to purple stain.

Of the nine cultivars tested, Jupiter and Ransom were most susceptible to purple stain (table 1). Jupiter, which was developed in Guyana by the University of Florida, has a greater vegetative growth than that of most other soybean cultivars when grown at low latitudes in the tropics (21). For this reason, this cultivar has been widely used both as a commercial variety and in soybean breeding programs in tropical countries. In Ecuador, for instance, Jupiter selections and Jupiter by Davis progenies are widely used in the breeding program and as commercial varieties. Since both Davis and Jupiter are susceptible to purple stain, it is small wonder that serious outbreaks of purple stain are common in that country. Soybean breeding programs should develop on a broad genetic base which includes high yielding and multiple disease resistant varieties as parental stocks. This is more important in the tropics because diseases and pests are more diverse and cause greater damage. In this study, Buffalo, a variety which has shown resistance to a number of races of soybean mosaic virus (5), was shown susceptible to purple stain. Buffalo has shown susceptibility to anthracnose (Colletotrichum dematium). ${ }^{4}$ Experience in temperate countries has illustrated that the concentration of effort on improving single gene resistance for a specific disease can backfire if the source of resistance carries genes for susceptibility to other diseases.

During the course of the experiment, mean temperatures were within the range $\left(24\right.$ to $30^{\circ} \mathrm{C}$ ) considered optimal for C. kikuchii sporulation in the tropics (11), and close to that reported in temperate areas (23 to $27^{\circ}$ C) $(29,35)$. Little variation in either minimum or maximum temperatures or their means was found (table 2). These were not correlated with purple stain incidence. González-Rodriguez (12) found a low (less than 0.4) significant correlation of temperature and conidia counts in two plantings in Puerto Rico. Variation of conidia counts was largely explained by differences in plant maturity. In Puerto Rico, variation in photoperiod is much greater than that of temperature. The difference of the shortest and longest days is over $25 \%$, whereas the variation of warmest to coldest month is less than $10 \%$. Over the experimental period, mean monthly precipitation exceeded $150 \mathrm{~mm}$. All months exceeded $80 \mathrm{~mm}$ monthly precipitation except December and February. González-Rodríguez (12) found no significant correlation between precipitation and conidia trapped in Isabela. The humid coast of Puerto Rico appears to provide temperature and precipitation favoring purple stain throughout most of

${ }^{4} \mathrm{G}$. R. Bowers, Jr., unpublished data. 
TABLE 2.-Variation of rainfall and temperature during the experimental period February through December 1979 in Isabela, Puerto Rico

\begin{tabular}{|c|c|c|c|c|c|c|}
\hline \multirow{3}{*}{ Month } & \multicolumn{2}{|c|}{ Precipitation (in.) } & \multicolumn{4}{|c|}{ Temperature (F) } \\
\hline & \multirow{2}{*}{ Total } & \multirow{2}{*}{ Greatest } & \multicolumn{2}{|c|}{ Range } & \multicolumn{2}{|c|}{ Mean } \\
\hline & & & Maximum & Minimum & Maximum \& S.E. & Minimum \& S.E. \\
\hline February & 1.60 & 0.56 & 86 & 60 & $81.5 \& 0.3$ & $64.1 \& 0.5$ \\
\hline March & 3.10 & 0.82 & 89 & 59 & $82.0 \& 0.7$ & $65.4 \& 0.5$ \\
\hline April & 7.67 & 2.80 & 89 & 62 & $81.7 \& 0.5$ & $67.1 \& 0.5$ \\
\hline May & 10.56 & 2.64 & 86 & 64 & $83.5 \& 0.3$ & $69.1 \& 0.6$ \\
\hline June & 7.70 & 1.58 & 88 & 69 & $85.1 \& 0.2$ & $70.3 \& 0.3$ \\
\hline July & 5.08 & 0.96 & 87 & 66 & $85.6 \& 0.2$ & $70.2 \& 0.4$ \\
\hline August & 3.63 & 1.30 & 88 & 70 & $86.1 \& 0.2$ & $70.8 \& 0.2$ \\
\hline September & 11.16 & 3.55 & 88 & 62 & $84.5 \& 0.5$ & $69.1 \& 0.4$ \\
\hline October & 9.15 & 1.53 & 90 & 64 & $86.2 \& 0.2$ & $68.6 \& 0.3$ \\
\hline November & 8.90 & 1.00 & 86 & 64 & $83.4 \& 0.4$ & $68.1 \& 0.4$ \\
\hline December & 1.58 & 1.00 & 84 & 61 & $81.5 \& 0.4$ & $66.4 \& 0.6$ \\
\hline
\end{tabular}




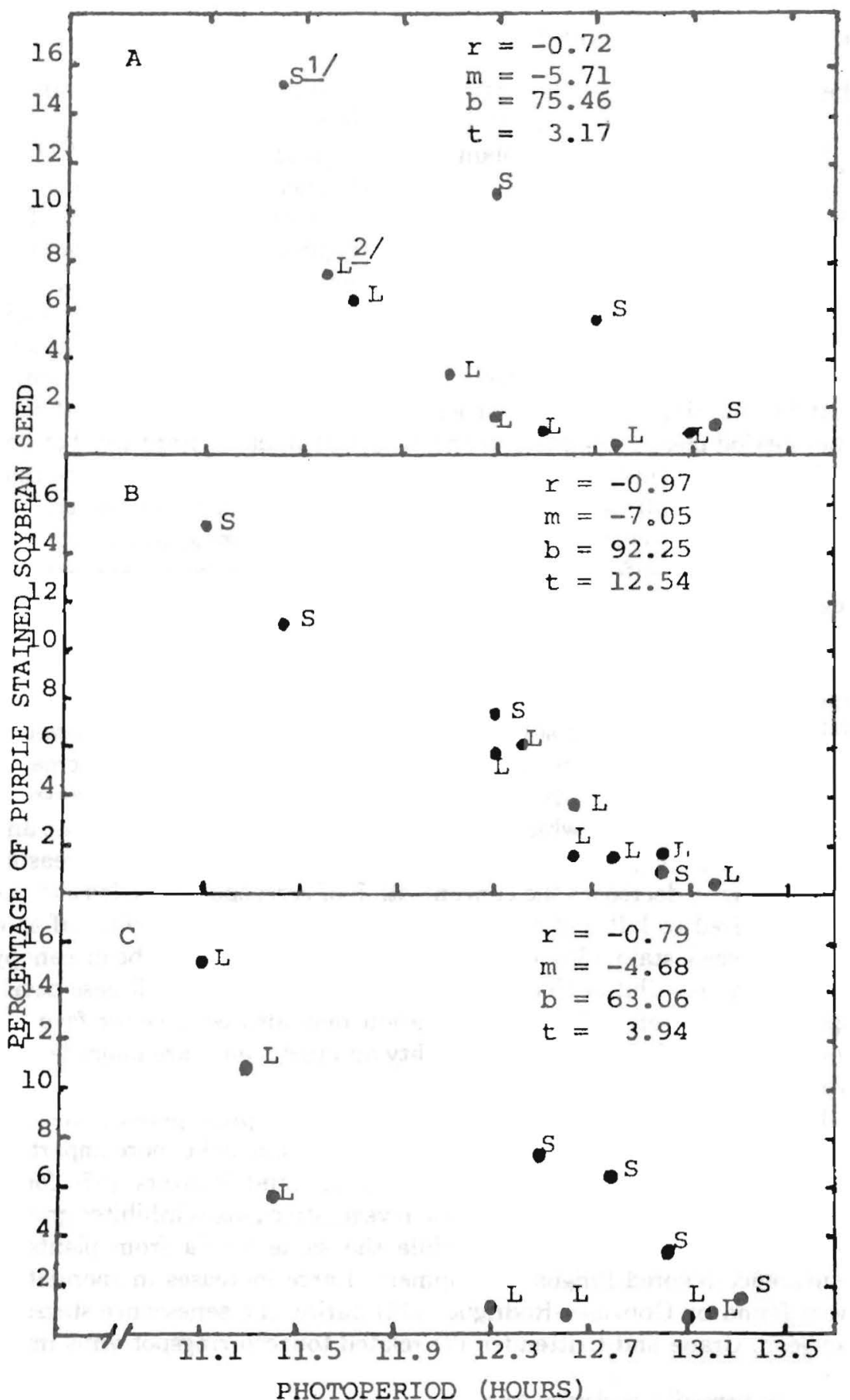

FIG. 1.-Relationship of photoperiod length at A) planting; B) 30 days after planting; and C) 75 days after planting with purple stain of soybean (Glycine max), at harvest maturity in Isabela, Puerto Rico. $\mathrm{S}=$ days were getting shorter at the beginning of the planting season; $\mathrm{L}=$ days were getting longer at the beginning of the planting season. 
the planting season. In low rainfall areas and in cooler upland areas, purple stain is notably reduced in Puerto Rico ${ }^{5}$.

Increased photoperiod at planting, 30 days after planting, and at 75 days after was associated with reduced incidence of purple stain (fig. 1). Of the three measurements of photoperiod, photoperiod at 30 days after planting was more highly associated with purple stain incidence ( $r=$ $-0.97)$ than that at planting $(r=-0.72)$ or 75 days after planting $(r=$ -0.79 ). Scatter diagrams of photoperiod length versus purple stain incidence show that for planting seasons under shortening days the relationship of photoperiod and purple stain incidence was more negative than that for planting seasons under lengthening days. This was found with photoperiod measurements at planting and at 75 days afterwards but not with measurements at 30 days after planting (fig. 1). It appears that photoperiod at 30 days after planting is a better index of the critical photoperiod for vegetative development than other measurements.

Major visible effects of short photoperiod on soybeans are reduced vegetative growth and early flowering. Using production practices of temperate zones results in a failure to form an inter-row canopy, which is extremely important in weed control and in obtaining optimum yield. Failure to produce a between row canopy also increased aeration and light around developing soybean plants in crucial stages of $C$. kikuchii infection and dispersal. Several Cercospora diseases ${ }^{6}$ have been increased under high light intensity. C. kikuchii and other species of Cercospora form a purple pigment which has been shown toxic to plant, animal, and bacterial cells in presence of light but not in the dark (9). Increasing light intensity decreases the concentration of cercosporin needed and the time required to kill test cells. The distribution of $C$. kikuchii leaf spot (38) and seed stain (30) in the upper portion of the soybean canopy support the possibility that light intensity may influence disease development and severity. Increased aeration may also be a factor favoring conidia dispersal. Fluctuating humidity and turbulence are major factors which control conidia release (12).

Physiological changes associated with short photoperiods are less obvious than morphological ones; however, these may be more important in relation to disease resistance. Vathakos and Walters (37) found soybean media from leaves of plants in vegetative stages inhibited growth and sporulation of $C$. kikuchii while the same media from plants in senescence favored fungus development. Large increases in sporulation were found by González-Rodriguez (12) during the senescence stages of soybean. Crane and Crittenden (7) related tobacco ringspot virus infec-

${ }^{5}$ P. R. Hepperly, unpublished data.

${ }^{6} \mathrm{~J}$. López-Rosa, unpublished data. 
tion of soybean with increased purple stain and increased length of flowering a critical stage for C. kikuchii infection.

Although the strong association found in this work between photoperiod length and purple stain incidence suggests short photoperiod may be a factor which helps explain the severity of purple stain in the tropics, it does not explain how shortened photoperiod affects the plant and/or fungus to bring this phenomenon about. The details of the exact mechanism which controls this predisposition deserves further study.

\section{RESUMEN}

La incidencia de la mancha púrpura de la soya se evaluó en nueve variedades comerciales que se sembraron en 11 fechas diferentes desde febrero a octubre de 1979 en Isabela, Puerto Rico. La mayor incidencia de semillas con la mancha púrpura apareció en las variedades "Ransom" (9.5\%) y "Jupiter" (8.3\%). Las variedades "IAC-2" (0.3\%) e "Improved Pelican" $(0.2 \%)$ mostraron los niveles más bajos de la mancha púrpura. No se observó correlación significativa entre los niveles de temperatura y lluvia y la incidencia de la mancha púrpura. Se observaron correlaciones negativas altas entre la incidencia de la mancha púrpura y el largo del fotoperiodo al momento de sembrar $(r=-0.72), 30$ dias después de sembrar $(r=0.97)$ y a los 75 días después de sembrar $(r=-0.79)$. Los fotoperíodos cortos aparentemente pueden predisponer las plantas de soya al ataque de la mancha púrpura. Esto puede explicar las incidencias altas de la mancha púrpura en áreas tropicales.

\section{LITERATURE CITED}

1. Abney, T. S. and Richards, T. L., 1980. Virulent isolates of Cercospara kikuchii from seed cause leaf blight of soybeans in Midwest, Mycol. Soc. Am. Newsl. 31:32.

2. Agarwal, V. K., Singh, O. V., Thapliyal, P. N., and Malhotra, R. K., 1973. Soybean (Glycine max), purple stain (Cercospora kikuchii). Am. Phytopath. Soc., Fungicide and Nematicide Tests, Results of 1972. 28:100.

3. Athow, K. L., 1976. Pathological factors affecting seed quality: in World Soybean Research, Lowell Hill (Ed). The Interstate Printers \& Publishers, Inc., Danville, IL.

4. — and Laviolette, F. A., 1973. Pod protection effects on soybean germination and infection with Diaporthe phaseolorum var. sojae and other microorganisms. Phytopathology 63:1021-023 (Abstr.).

5. Bowers, G. R., Jr., 1980. The inheritance of resistance to soybean mosaic virus in soybeans and studies on seed transmission, $\mathrm{Ph} . \mathrm{D}$. thesis, Univ. of Ill., Urbana.

6. Chamberlain, D. W., 1963. Spot and stop soybean diseases II. The leaves and seeds, Crops and Soils $15(8): 16-7$.

7. Crane, J. L. and Crittenden, H. W., 1962. Effect of deflowering and tobacco ringspot virus on the occurrence of Cercospora kikuchii in soybean, Phytopathology 62:1217 (Abstr.).

8. — and - $\longrightarrow, 1966$. The relation of soybean seed infected by Cercospora kikuchii to the duration of certain plant developmental stages, Plant Dis. Rep. 50:464-68. 
9. Daub, M. E., 1982. Cercosporin, a photosensitiving toxin from Cercospora species, Phytopathology 72:370-74.

10. Deutschmann, F., 1953. On the purple stain disease of the soybean and the pigment formation by its agent, Cercospora kikuchii. Phytopath. Z. 20:297-310.

11. Díaz, C., 1966. Cercospora kikuchii en soya, nuevo patógeno en Venezuela. Agron. Trop. $16: 213-21$.

12. González-Rodríguez, J. A., 1976. Efectos de la cantidad de inóculo en la epidemiologia de la mancha púrpura de la semilla de soya, Master's Thesis, Univ. P. R., Mayagüez.

13. Goodman, R. M. and Oard, J. H., 1980. Seed transmission and yield losses in tropical soybeans infected by soybean mosaic virus, Plant Disease 64:913-14.

14. - Sinclair, J. B. and Hepperly, P. R., 1981. Plant pathology and the international soybean program (INTSOY), Plant Disease 65(3): 214-22.

15. Han, Y. S., 1959. Studies on purple spot of soybean, J. Agr. and For. 8:1-32.

16. Hartwig, E. E., 1970. Growth and reproductive characteristics of soybeans (Glycine max (L.) Merr.) grown under short day conditions, Trop. Sci. 12:47-53.

17. - 1973. Varietal development in soybeans: in Soybeans: Improvement, Production, and Uses. B. E. Caldwell (Ed). Agronomy 16. Am. Soc. Agron., Madison, Wisconsin.

18. Hepperly, P. R. and Sinclair, J. B., 1980. Detached pods for studies of Phomopsis sojae pod and seed colonization, J. Agric. Univ. P. R. 64:330-36.

19. — , and — 1981. Relationships among Cercospora kikuchii, other seed mycoflora, and germination of soybeans in Puerto Rico and Illinois, Plant Disease 65:130-32.

20. Hinson, K., 1975. Tropical production of soybeans: in Proc. Workship on Soybeans for Tropical and Subtropical Conditions, INTSOY Series 2:38-54. College of Agriculture, University of Illinois, Urbana.

21. — and Hartwig, E. E., 1977. Soybean Production in the Tropics, FAO Plant Production and Protection Paper 35. Rome, Italy.

22. Hymowitz, T., 1970. On the domestication of the soybean, Econ. Bot. 24:408-21.

23. Johnson, H. W. and Jones, J. P., 1962. Purple stain of guar, Phytopathology 52:269 72.

24. Jones, J. P., 1959. Purple stain of soybean seeds incited by several Cercospora species, Phytopathology 49:430-32.

25. Kulik, M. M., 1957. Purple stained soybean seed, Phytopathology 47:22 (Abstr.).

26. Kuyama, S. and Tamura, T., 1957. Cercosporin, a pigment of Cercospora kikuchii. Am. Chem. Soc. J. 79:5725-729.

27. Laviolette, F. A. and Athow, K. L., 1972. Cercospora kikuchii infection of soybean as affected by stage of plant development, Phytopathology 62:771 (Abstr.).

28. Lehman, S. G., 1950. Purple stain of soybean seeds, N. C. Agric. Exp. Stn. Bull. 369.

29. Murakishi, H. H., 1951. Purple stain of soybean, Phytopathology 41:305-18.

30. Roy, K. W. and Abney, T. S., 1976. Fungal colonization of soybean pods and seeds, Proc. Am. Phytopath. Soc. 2:89 (Abstr.).

31. — and - 1976. Purple seed stain of soybeans. Phytopathology 66:1045-049.

32. - , and - , 1977. Antagonism between Cercospora kikuchii and other seedborne fungi of soybeans, Phytopathology 67:1062-066.

33. Salaues, E., 1978. Efectos de fotoperiodo en las características fenológicas de cultivares de soya (Glycine $\max$ (L.) Merr.) cultivados en diferentes épocas, Master's Thesis, Univ. P. R., Mayagüez.

34. Sherwin, H. S. and Kreitlow, K. W., 1952. Discoloration of soybean seeds by the frogeye fungus, Cercospora sojina. Phytopathology 42:568-72.

35. Sinclair, J. B. (Ed), 1982. Compendium of Soybean Diseases. Am. Phytopath. Soc., St. Paul, MN.

36. Tenne, F. D. and Sinclair, J. B., 1978. Control of internally seedborne microorganisms of soybean with foliar fungicides in Puerto Rico, Plant Dis. Rep. 62:459-63. 
37. Vathakos, M. G. and Walters, H. J., 1979, Production of conidia by Cercospora kikuchii in culture, Phytopathology 69:832-33.

38. Walters, H. J., 1980. Soybean leaf blight caused by Cercospora kikuchii. Plant Disease 64:961-62.

39. Wilcox, J. R. and Abney, T. S., 1973. Effects of Cercospora kikuchii on soybeans, Phytopathology 63:796-97.

40. Wilcox, J. R., Laviolette, F. A. and Athow, K. L., 1974. Deterioration of soybean seed quality associated with delayed harvest, Plant Dis. Rep. 58:130-33.

41. - - - and Martin, R. J., 1975. Heritability of purple stain resistance in soybeans, Crop Sci. 15:525-26. 